\title{
Evaluasi Pelaksanaan Program Percepatan Penganekaragaman Konsumsi Pangan di Kecamatan Mattiro Sompe Kabupaten Pinrang
}

\author{
Evaluation of the Food Consumption Diversification Acceleration Program Implementation \\ in Mattiro Sompe District, Pinrang Regency
}

\author{
Bahar Mani, Program Studi Agribisnis Universitas Muhammadiyah Parepare \\ baharXmani@gmail.com
}

\begin{abstract}
Abstrak
Program pemanfaatan pekarangan yang telah dilaksanakan oleh Kelompok Wanita di Kabupaten Pinrang, Program ini dinamakan Percepatan Penganekaragaman Konsumsi Pangan $(P 2 K P)$ berbasis sumber daya lokal yang melibatkan instansi terkait diantaranya Kantor Ketahanan pangan, Dinas Pertanian, Dinas Kesehatan, Dinas Pendidikan Pemuda dan Olah Raga, Dinas Perindustrian Perdagangan dan Energi serta Tim Penggerak PKK se Kabupaten Pinrang. Penelitian ini bertujuan untuk mengetahui capaian pelaksanaan program Percepatan Penganekaragaman Konsumsi Pangan (P2KP) melalui optimalisasi pemanfaatan pekarangan dan diversifikasi pangan. Pendekatan yang digunakan dalam penelitian ini adalah deskriptif kualitatif. Dengan informasi dari 80 informan dan instansi tersebut diatas, diperoleh gambaran bahwa partisipasi kelompok wanita P2KP di Kecamatan Mattiro Sompe Kabupaten Pinrang secara optimal dilaksanakan oleh 50\% responden atau 40 orang kelompok wanita P2KP. Pola konsumsi pangan masih mengandalkan beras sebagai bahan makanan pokok dan pola konsumsi padi - padian masih sangat rendah.
\end{abstract}

Kata Kunci : diversifikasi pangan, pola konsumsi, P2KP

\section{Abstract}

The land utilization program implemented by the Women's Group in Pinrang Regency, this program is called local resource-based Acceleration of Food Consumption $(P 2 K P)$ involving relevant agencies including the Office of Food Security, Department of Agriculture, Health Service, Youth and Sports Education Agency, The Department of Industry and Trade in Energy and the PKK Driving Team in Pinrang District. This study aims to determine the achievements of the implementation of the Food Consumption Diversification Acceleration program (P2KP) through optimizing the utilization of the yard and food diversification. The approach used in this research is descriptive qualitative. With the 80 informants and information from the above-mentioned agencies, obtained a description that the participation of women's groups in the District Mattiro Sompe P2KP Pinrang optimally implemented by $50 \%$ of respondents, or 40 people P2KP women's groups. Food consumption patterns still rely on rice as a staple food and grain consumption patterns are still very low.

Keywords: food diversification, consumption patterns, $P 2 K P$

\section{Pendahuluan}

Pola konsumsi pangan masyarakat dikenal sangat beragam. Pemenuhan kebutuhan akan konsumsi pangan menjadi hal yang sangat penting dan strategis mengingat pangan adalah kebutuhan dasar manusia. Ketahanan pangan di suatu wilayah diukur dari ketersediaan pangan, daya beli, dan tingkat konsumsi. Dari aspek gizi, Kecukupan konsumsi energi dan protein dapat menjadi indikator yang 
digunakan untuk analisis tingkat konsumsi masyarakat (Saputri, dkk., 2016). Konsumsi energi dan protein yang dianjurkan sebesar $2.150 \mathrm{kkal} / \mathrm{kapita} / \mathrm{hari}$ dan kecukupan konsumsi protein adalah sebesar $57 \mathrm{~g} /$ kapita/hari sesuai kesepakatan bersama dalam Widyakarya Nasional Pangan dan Gizi X (WNPG) tahun 2012 (Mahyuni, 2012).

Sektor Pertanian menjadi berpengaruh terutama terhadap gizi melalui produksi pangan. Jika jumlah dan ragam pangan yang diproduksi cukup, ditambah harga yang terjangkau oleh semua lapisan masyarakat maka ketahanan pangan dapat terwujud sesuai yang diharapkan. Untuk diketahui penyebab dominan kerawanan pangan adalah banyaknya jumlah penduduk yang belum mampu menjangkau harga pangan yang tersedia (Safitri, 2017).

Upaya membudayakan pola konsumsi pangan yang beragam, bergizi seimbang dan aman dalam jumlah serta komposisi yang cukup telah banyak dilakukan. Hal ini bertujuan guna memenuhi kebutuhan gizi untuk mendukung hidup sehat, aktif dan produktif. Upaya tersebut melalui penganekaragaman konsumsi pangan sebagai indikator untuk mengukur tingkat keanekaragaman dan keseimbangan (Hastuty, 2013).

Kementerian Pertanian melalui Badan Ketahanan Pangan 2016 mencatat bahwa penganekaragaman konsumsi pangan masyarakat Indonesia dengan indikator skor Pola Pangan Harapan (PPH), menunjukkan skor mutu konsumsi pangan penduduk Indonesia periode 2006-2016 terjadi fluktuasi. Hal ini diindikasikan terjadinya penurunan Skor PPH dari 81,9 pada tahun 2008 menjadi 78,8 pada tahun 2009. Pada tahun 2010 skor PPH kembali meningkat yaitu 80,6 dan tahun 2016 meningkat menjadi 83,4 tetapi masih didominasi konsumsi energi kelompok padi-padian dari proporsi sebesar 50 persen, hal ini terjadi karena kurangnya kesadaran masyarakat akan pangan yang beragam, bergizi, seimbang, dan aman, dan diikuti juga dengan semakin meningkatnya konsumsi terigu yang merupakan bahan pangan impor. Sementara itu, konsumsi pangan yang lainnya masih belum memenuhi komposisi ideal yang dianjurkan, seperti pada kelompok umbi - umbian, pangan hewani, sayur dan buah.

Beberapa kajian menunjukkan bahwa meskipun penganekaragaman konsumsi pangan telah menjadi program sejak lebih dari 45 tahun yang lalu, namun tingkat keberhasilan program tersebut sampai saat ini belum sesuai dengan yang diharapkan (Krisnamurthi 2003, Rachman dan Ariani 2008, Martianto, dkk. 2009).

Menyadari hal tersebut, Pemerintah Indonesia sejak tahun 60 -an telah merintis upaya perbaikan kualitas makanan dan gizi keluarga, melalui program atau kegiatan perbaikan menu makanan rakyat. Peningkatan Diversifikasi Pangan (Penganekaragaman Pangan) menjadi salah satu kontrak kerja antara Menteri Pertanian dengan Presiden selama tahun 2009 - 2014, dengan tujuan untuk meningkatkan keanekaragaman pangan sesuai dengan karakteristik daerah. Kontrak kerja ini merupakan tindak lanjut dari Peraturan Presiden (Perpres) No. 22 Tahun 2009 tentang Kebijakan Percepatan Penganekaragaman Konsumsi Pangan Berbasis Sumber Daya Lokal, yang ditindaklanjuti oleh Peraturan Menteri Pertanian (Permentan) No. 43 Tahun 2009 tentang Gerakan Percepatan Penganekaragaman Konsumsi Pangan (P2KP) Berbasis Sumber Daya Lokal. Peraturan tersebut menjadi acuan yang dapat mendorong percepatan penganekaragaman konsumsi pangan berbasis sumber daya lokal melalui kerja sama sinergis antara pemerintah dan pemerintah daerah. Di Provinsi, kebijakan tersebut ditindaklanjuti dengan Peraturan Gubernur (Pergub) dan di kabupaten/kota ditindaklanjuti dengan Peraturan Bupati/Walikota (Perbup/Perwalikota).

Berbagai permasalahan dan yang muncul yang harus segera diantisipasi, terutama dalam mewujudkan pola 
konsumsi pangan yang beragam bergizi seimbang dan aman. Penelitian ini bertujuan untuk mengetahui capaian pelaksanaan program Percepatan Penganekaragaman Konsumsi Pangan (P2KP) melalui optimalisasi pemanfaatan pekarangan dan diversifikasi pangan.

\section{Metode Penelitian}

Penelitian ini dilaksanakan di Kecamatan Mattiro Sompe Kabupaten Pinrang. Pendekatan yang digunakan deskriptif kualitatif, sehingga dalam penelitian ini tidak dikenal adanya sampel melainkan informan. Hal ini dibutuhkan untuk dapat memperoleh informasi yang lebih jelas mengenai masalah penelitian. Penentuan informan dianggap mengetahui objek penelitian, informan yang dipilih juga disesuaikan dengan tujuan dan kebutuhan penelitian (Halimah, 2016). Adapun informan dalam penelitian ini adalah kelompok wanita di lokasi penelitian. Jumlah kelompok wanita P2KP yang terdapat di lokasi penelitian yaitu kelompok wanita Suka Maju Desa Siwolong Polong dengan jumlah anggota 20 orang, kelompok Wanita Nur Annisa dengan jumlah anggota 20 orang, Kelurahan langnga jumlah anggota 40 orang. Semua anggota dijadikan sampel, sehingga jumlah informan 80 orang. Selain itu, dari pihak pemerintah masingmasing adalah Badan Ketahanan pangan, Dinas Pertanian, Dinas Kesehatan, Dinas Pendidikan Pemuda dan Olah Raga, Dinas Perindustrian Perdagangan dan Energi serta Tim Penggerak PKK Kabupaten Pinrang.

Dalam penelitian ini yang menjadi perhatian utama adalah kegiatan partisipasi kelompok wanita sebagai sasaran program P2KP tahun 2016 di Kabupaten Pinrang. Metode deskriptif bertujuan untuk menggambarkan pola konsumsi ibu rumah tangga/wanita menuju komposisi menu makanan ke arah B2SA, dan optimalisasi pemanfaatan pekarangan oleh kelompok wanita.

\section{Hasil dan Pembahasan}

\section{Optimalisasi Pemanfaatan Pekarangan}

Laporan perkembangan evaluasi pelaksanaan program P2KP Kabupaten Pinrang tahun 2016 yang dilaksanakan oleh Kantor Badan Ketahanan Pangan melalui Penanggung Jawab Kasi Kewaspadaan Pangan, Gizi, dan Penganekaragaman Konsumsi Pangan Badan Ketahanan Pangan Kabupaten Pinrang adalah sebagai berikut :

a. Percepatan Penganekaragaman Konsumsi Pangan (P2KP) di Kabupaten Pinrang yang telah dilaksanakan sejak Tahun 2010 sampai 2016 oleh 30 Kelompok Wanita Tani (KWT) di desa/kelurahan yang tersebar di 12 kecamatan. Di laporkan bahwa sudah diterbitkan Peraturan Bupati No. 08 Tahun 2011 tertanggal 31 Maret 2011 melalui Surat Edaran Bupati Pinrang tentang Gerakan Percepatan Penganekaragaman Konsumsi Pangan (P2KP) Berbasis Sumber Daya Lokal dan Surat Edaran Bupati Pinrang

b. Kegiatan Optimalisasi Pemanfaatan Pekarangan dilaksanakan oleh 30 kelompok dan hingga saat ini masih berjalan baik. Perkembangan anggota kelompok yang dapat dilaporkan antara lain Kelompok 2010, kelompok 2016 (pokok) dan kelompok 2016 (APBN).

Tujuan kegiatan P2KP yaitu 1) meningkatkan kesadaran dalam mewujudkan pola konsumsi pangan yang B2SA serta mengurangi ketergantungan terhadap bahan pangan pokok beras; 2) Meningkatkan partisipasi kelompok wanita dalam penyediaan sumber pangan dan gizi keluarga melalui optimalisasi pemanfaatan pekarangan sebagai pengahasil sumber karbohidrat, protein, vitamin dan mineral untuk konsumsi keluarga; dan 3) Mendorong pengembangan usaha pengolahan pangan sumber karbohidrat selain beras dan terigu (BKP, 2013). 
Pemanfaatan lahan pekarangan merupakan salah satu kegiatan yang dilaksanakan dalam rangka Percepatan Penganekaragaman Konsumsi Pangan. Pekarangan adalah sebidang tanah disekitar rumah yang mudah diusahakan dengan tujuan untuk meningkatkan pemenuhan gizi mikro melalui perbaikan menu keluarga. Kegiatan pemanfaatan pekarangan merupakan kegiatan yang sudah lama dilaksanakan dalam rangka menyediakan bahan makanan atau komoditas pertanian yang bukan saja berfungsi sebagai penyediaan bahan makanan yang beranekaragam akan tetapi juga dapat berfungsi sebagai penghasilan keluarga (Hastuty, 2013).

$$
\text { Menurut Siti, }
$$

memanfaatan pekarangan di lahan sekitar rumah sangat penting untuk menjaga kualitas ekosistem yang dapat menjamin ketersediaan sebagian pangan keluarga. Adapun jenis-jenis tanaman yang dibudidayakan biasanya adalah tanaman yang mempunyai nilai ekonomis tinggi, berumur pendek, atau tanaman semusim khususnya sayuran (Kusmiati dan Sholikhah, 2015).

Tabel 1 menunjukan adanya peningkatan jumlah anggota kelompok di setiap desa, dengan persentase penambahan yang berbeda-beda. Akumulasi persentase peningkatan partisipasi kelompok wanita dalam penyediaan sumber pangan keluarga melalui pemanfaatan pekarangan adalah $63,8 \%$. Indikator keberhasilan program ini dilakukan dengan membandingkan pengetahuan dan pemahaman warga sebelum dan sesudah kegiatan. Secara umum dapat menunjukkan bahwa terjadi peningkatan partisipasi dan pengetahuan
KWT dalam memanfaatkan pekarangan secara optimal. Menurut Dwiratna, dkk (2016), optimalisasi pemanfaatan pekarangan dapat membantu ketahanan pangan keluarga.

Kecamatan Lanrisang adalah salah satu kecamatan yang melaksanakan program P2KP di tiga desa/kelurahan, yakni Kelurahan Langnga, Desa Siwolong Polong, dan Desa Patobong. Desa Siwolong Polong adalah Desa penerima manfaat anggaran tahun 2014, Desa Patobong dan kelurahan Langnga penerima manfaat anggaran tahun 2015. Perkembangan kelompok wanita Desa Siwolong Polong dapat dilihat dari replikasi kelompok yang dibentuk sebanyak dua kelompok, Desa Patobong dua kelompok, dan kelurahan Langnga satu kelompok dengan jumlah anggota masing-masing kelompok 10-15 orang.

Tujuan pemberdayaan kelompok wanita ini dimaksudkan untuk (1) meningkatkan pola pikir, keterampilan dan perubahan pola sikap kelompok wanita dalam mengkonsumsi pangan beragam, bergizi seimbang dan aman; (2) Meningkatkan keterampilan kelompok wanita dalam menyusun, mengolah dan menyajikan menu makanan beragam, bergizi seimbang dan aman dengan memanfaatkan bahan pangan hasil pekarangan sendiri dan mengurangi sajian nasi dalam menu makanan sehari-hari, dan (3) meningkatkan citra positif pangan sumber karbohidrat selain beras dan terigu. Besarnya partisipasi kelompok wanita dalam pemanfaatan pekarangan sebagai penghasil karbohidrat, vitamin, mineral dan protein untuk konsumsi keluarga di Kecamatan Lanrisang Kabupaten Pinrang dapat dilihat pada tabel 1 .

Tabel 1 Partisipasi Kelompok Wanita melalui Optimalisasi Pemanfaatan Pekarangan.

\begin{tabular}{cccccc}
\hline \multirow{2}{*}{ No } & Golongan & Jenis & Tanaman yang & \multicolumn{2}{c}{ Responden } \\
& Komoditas & \multicolumn{2}{c}{ dipelihara } & orang & $\%$ \\
\hline \multirow{2}{*}{1} & Karbohidrat & - & Jagung & 30 & 37 \\
& & - & Ubi kayu & 40 & 50 \\
& & - & Ubi jalar & 20 & 25 \\
\hline
\end{tabular}




\begin{tabular}{|c|c|c|c|c|}
\hline & & - $\quad$ Pisang & 40 & 50 \\
\hline \multirow[t]{4}{*}{2} & Protein & Ayam & 50 & 62 \\
\hline & & - itik & 30 & 37 \\
\hline & & - Ikan & 2 & 2,5 \\
\hline & & - $\quad$ Kambing & 7 & 8,7 \\
\hline \multirow[t]{12}{*}{3.} & Vitamin dan & - Sawi & 40 & 50 \\
\hline & Mineral & - Bayam & 37 & 46 \\
\hline & & - Kangkung & 30 & 37 \\
\hline & & - Lombok & 60 & 75 \\
\hline & & - $\quad$ Labu & 20 & 25 \\
\hline & & - Melon & 10 & 12,5 \\
\hline & & - Tomat & 40 & 50 \\
\hline & & - $\quad$ Terong & 50 & 62 \\
\hline & & - Gambas & 25 & 31 \\
\hline & & - Kol & 5 & 6,2 \\
\hline & & - $\quad$ Bawang Prey & 40 & 50 \\
\hline & & - Pepaya & 35 & 43 \\
\hline
\end{tabular}

Sumber : Data Diolah, 2016

Informan mengakui jika semua anggota telah melaksanakan pemanfaatan pekarangan dengan berbagai jenis komoditas. Melalui Program P2KP mereka mendapat pengetahuan bahwa untuk membudidayakan tanaman tidak harus pada lahan yang luas, tetapi mereka dapat memanfaatkan lahan yang sempit seperti pekarangan rumah. Mereka memahami secara jelas program pemanfaatan lahan pekarangan ini mempunyai nilai manfaat yang besar bagi rumah tangga yang meliputi pemenuhan perbaikan gizi keluarga, terjaminnya bahan pangan yang bermutu dan higienis, mengurangi pengeluaran keluarga, dan menambah pendapatan keluarga.

Dengan demikian, pentingnya pemanfaatan lahan pekarangan masyarakat akan pemenuhan perbaikan gizi keluarga. Lahan pekarangan mempunyai potensi yang besar dalam rangka mendukung ketahan pangan rumah tangga. Hal ini dapat dibuktikan dengan adanya pemenuhan kebutuhan gizi dan pendapatan keluarga yang timbul dari pemanfaatan lahan pekarangan. Potensi ini dapat dilihat dengan mengelola lahan pekarangan dengan baik, misalnya dengan penanaman komoditas sayur-sayuran, memelihara ternak kambing atau sapi, dan budidaya ikan (Istikhomah dan Rhina, 2016).

Tabel 1 juga menunjukkan optimalisasi pekarangan dengan memelihara ternak seperti ayam, itik dan kambing, yang telah dilaksanakan oleh sebagian anggota kelompok. Ikan sebagai sumber protein juga telah dipelihara oleh anggota kelompok walaupun hanya 2 orang informan.

Pemeliharaan binatang ternak hanya diusahakan secara sambilan, hal ini ditunjukkan pada Tabel 2. Dari 80 informan yang memelihara ternak semua hasilnya hanya untuk konsumsi keluarga. Hal ini merupakan permasalahan yang dihadapi pada optimalisasi pemanfaatan pekarangan saat ini karena kegiatan yang dilakukan belum berorientasi ekonomi. Secara umum pengelolaan pekarangan di daerah ini bukan untuk tujuan memperoleh pendapatan, hanya bersifat sambilan. Hasil dari pekarangan sebagian besar hanya untuk memenuhi kebutuhan sendiri. Hal ini sesuai yang dikemukakan oleh Nurwati, dkk. (2015) bahwa pemanfaatan pekarangan di beberapa daerah bercorak usahatani subsisten, artinya sebagian besar hanya bersifat sambilan untuk mengisi waktu luang dan diutamakan untuk pemenuhan kebutuhan keluarga. 
Untuk mengetahui pemanfaatan hasil pekarangan pasca panen kelompok wanita Program P2KP Kecamatan Mattiro Sompe
Kabupaten Pinrang tahun 2014 - 2016 dapat dilihat pada Tabel 2.

Tabel 2. Pemanfaatan Hasil Pekarangan Pasca Panen, Kelompok Wanita P2KP Kecamatan Mattiro Sompe Kabupaten PinrangTahun 2014 -2016

\begin{tabular}{lccccccc}
\hline & \multirow{6}{*}{$\begin{array}{c}\text { No } \\
\text { Golongan Komoditas }\end{array}$} & \multicolumn{5}{c}{ Jumlah Responden } \\
\cline { 2 - 7 } & \multicolumn{2}{c}{ Dijual } & \multicolumn{3}{c}{ Dikonsumsi } & \multicolumn{2}{c}{ Diolah } \\
\cline { 2 - 7 } 1 & Karbohidrat & 25 & 31 & 50 & 62 & 5 & 7 \\
2 & Protein & - & - & 80 & 100 & - & - \\
3 & $\begin{array}{c}\text { Vitamin dan } \\
\text { Mineral }\end{array}$ & 40 & 50 & 40 & 50 & - \\
\hline
\end{tabular}

Sumber : Data Diolah, 2016

Tabel 2. menunjukkan 40 informan, memanfaatkan hasil pekarangannya selain untuk konsumsi keluarga juga untuk dijual, sedangkan 40 informan hanya dimanfaatkan untuk kebutuhan keluarga. Sesuai penelitian Istikhomah dan Rhina (2016), bahwa pemenuhan kebutuhan pangan keluarga melalui pemanfaatan pekarangan akan mampu mengurangi jatah pengeluaran konsumsi sehari-hari. Hasil selebihnya setelah untuk pemenuhan kebutuhan keluarga, jika masih ada dapat dijual sehingga dapat menambah pendapatan keluarga.

Hasil wawancara dengan informan menggambarkan jika pemanfaatan pekarangan telah optimal dilaksanakan. Hampir semua pekarangan rumah peduduk di daerah ini dimanfaatkan dengan berbagai jenis tanaman. Dari hasil wawancara dengan ketua kelompok wanita Desa Mallongi-longi, juga diketahui bahwa optimalisasi pekarangan dengan aneka macam tanaman sayuran dan buah bukan hanya dilaksanakan oleh anggota kelompok wanita saja, tetapi sebagian besar warga desa telah menanam berbagai jenis tanaman di pekarangan rumah mereka.

Sepanjang jalan desa ditanami dengan tanaman produktif, misalkan kacang panjang, jagung, lombok kecil, dan sebagainya. Untuk melihat persentase pemanfaatan luas lahan pekarangan yang dimanfaatkan oleh responden dapat dilihat pada Tabel 3 .

Tabel 3 Optimalisasi Lahan Pekarangan yang dimanfaatkan

\begin{tabular}{ccc}
\hline Lahan yang Telah & \multicolumn{2}{c}{ Informan } \\
\cline { 2 - 3 } Dimanfaatkan $(\%)$ & Orang & $\%$ \\
\hline$(0-25)$ & 9 & 11 \\
$(26-50)$ & 16 & 20 \\
$(61-75)$ & 15 & 19 \\
$(76-100)$ & 40 & 50 \\
\hline Jumlah & 80 & 100 \\
\hline
\end{tabular}

Sumber : Data Diolah, 2016 
Tabel 3 menunjukkan optimalisasi pekarangan lahan pekarangan dengan memanfaatkan 76 - $100 \%$ lahan pekarangan yang ada telah dilaksanakan oleh $50 \%$ informan, $61-75 \%$ lahan dimanfaatkan oleh 15 atau $19 \%$ informan, 26 - $50 \%$ lahan telah dimanfaatkan oleh $20 \%$ atau 16 orang informan. $0-25 \%$ lahan telah dimanfaatkan oleh $11 \%$ informan atau hanya 9 informan.

Pemanfaatan lahan yang optimal hanya dilaksanakan oleh 40 orang informan atau $50 \%$ informan, hal ini disebabkan karena pemanfaatan pekarangan di daerah ini hanya bersifat sambilan saja tidak berorientasi ekonomi. Informan yang memanfaatkan lahannya 76 - $100 \%$ adalah informan yang hasil tanamannya selain untuk konsumsi juga untuk dijual. Sedangkan informan yang lain yang belum memanfaatkan lahan pekarangan secara optimal hanya menanam untuk konsumsi keluarga.

Peranan dan pemanfaatan pekarangan bervariasi dari satu daerah dengan daerah lainnya, tergantung pada tingkat kebutuhan, sosial, budaya, pendidikan masyarakat, maupun faktor fisik dan ekologi setempat (Rahayu dan Prawiroatmodjo, 2005). Pola Pertanian di lahan pekarangan lokasi penelitian umunya berupa campuran (multi komoditas). Di desa lokasi penelitian terdapat kebun percontohan bagi warga dan anggota kelompok. Desa Lerang adalah salah satu desa yang memiliki kebun percontohan yang bukan hanya dikunjungi oleh warga desa tetapi juga dijadikan pekarangan percontohan untuk tingkat kabupaten. Selain sebagai kebun percontohan, juga menyediakan bibit bagi warga yang ingin membudidayakan tanaman sayur dan buah. Menurut ketua kelompok wanita Mandiri Satu Desa Siwolong Polong, anggotanya termotivasi untuk memanfaatkan lahan kosong dan pekarangan rumah setelah salah seorang anggota kelompok secara serius memanfaatkan lahan kosong dengan menanam tanaman sawi. Anggota kelompok tersebut menanam sawi dengan tekun dan merawat dengan baik. Dengan luas areal pertanaman 2are, bisa menghasilkan sawi dengan harga jual sekali panen kurang lebih 3 juta rupiah. Hal ini yang membuat warga desa mengikuti langkah warga yang telah berhasil, sehingga hasil pekarangan bukan hanya dikonsumsi tetapi juga untuk dijual.

Dari pengamatan yang dilakukan, ada beberapa permasalahan yang dihadapi dalam pengembangan optimalisasi pekarangan di Kecamatan Mattiro Sompe Kabupaten Pinrang 2014- 2016 yaitu : (1) pemanfaatan lahan belum optimal, produktifitas tanaman relatif rendah, dan belum berorientasi ekonomi, (2) Sumber daya lahan pekarangan oleh sebagaian besar masyarakat dipandang sebagai sumberdaya yang kurang memberikan manfaat dibandingkan sumber daya lahan sawah dan lahan kering (3) Sistem usahatani pada lahan pekarangan umumnya berupa campuran aneka tanaman dan belum memperhatikan sistem budidaya yang baik (4) Pola pemilikan lahan pekarangan kecil dengan sistem usaha tradisional (5) Mutu hasil panen relatif rendah, (6) Belum dilakukan pengolahan lanjutan hasil sayur, buah dan umbi-umbian untuk memeperoleh nilai tambah (7) Lemahnya akses pasar bagi hasil-hasil produksi lahan pekarangan, karena volume kecil dan tersebar.

Karakteristik lahan pekarangan yang umumnya berupa lahan kering dan berlokasi dekat perumahan penduduk juga menyebabkan permasalahan keberlanjutan pemanfaatan lahan pekarangan. Kondisi ini mengakibatkan : (1) Mudahnya perubahan status lahan pekarangan menjadi penggunaan non pertanian seperti untuk garasi, lahan usaha (warung/toko) atau dibuat bangunan baru atau perluasan bangunan, (2) Perilaku tidak berkelanjutan dari pengelola (pemilik rumah) akibat bosan atau produksi yang sangat kecil. 


\section{Diversifikasi Pangan dalam Pola makan Masyarakat.}

Ditinjau dari potensi sumberdaya wilayah, sumberdaya alam Indonesia memiliki potensi ketersediaan pangan yang beragam dari satu wilayah ke wilayah lainnya, baik sebagai sumber karbohidrat maupun protein, vitamin dan mineral, yang berasal dari kelompok padipadian, umbiumbian, pangan hewani, kacang-kacangan, sayur dan buah dan biji berminyak. Potensi sumberdaya pangan tersebut belum seluruhnya dimanfaatkan secara optimal sehingga pola konsumsi pangan rumah tangga masih didominasi beras dan keanekaragaman konsumsi pangan dan gizi yang sesuai dengan kaidah nutrisi yang seimbang belum terwujud.

Diversifikasi bahan pangan merupakan upaya pemilihan pangan yag tidak bergantung pada satu jenis pangan. Diversifikasi atau penganekaragaman pangan dimaksudkan sebagai kombinasi makanan pokok, sayuran, dan buahbuahan yang diharapkan makin beragam dan seimbang komposisi pangan yang dikonsumsi akan makin baik pula kualitas gizi masyarakat (Suyastiri, 2008).

Diversifikasi konsumsi pangan diharapkan bukan hanya pada pangan pokok, akan tetapi pada semua bahan pangan yang dikonsumsi. Diversifikasi konsumsi pangan, disamping merupakan implementasi dari pola konsumsi pangan dalam menu makanan sehari-hari, juga dapat diartikan sebagai kemampuan meminimalkan konsumsi pangan tertentu terutama pada masa-masa sulit. Yang lebih penting dari itu adalah mengangkat citra pangan pokok lokal tradisional agar dapat bersaing dan bersanding dengan beras (Hanafie, 2010).

Hasil wawancara terkait pola konsumsi di kalangan informan menggambarkan bahwa pola makan informan dalam mengkonsumsi makanan utama sebanyak tiga kali dalam sehari, sedangkan 20 persen mengkonsumsi makanan utama hanya dua kali dalam sehari. Pola makan tiga kali sehari adalah pola makan yang umum di Indonesia. Pola konsumsi makan dua kali sehari menjelaskan bahwa sarapan pagi dengan segelas teh dan makanan ringan/ kue dianggap makanan selingan yang biasa diberikan pada pagi hari dan sore hari. Makanan selingan yang biasa mereka konsumsiadalah ubi kayu, ubi jalar, pisang, roti dan sebagainya. Bahan makanan tersebut diolah dalam bentuk kue, atau hanya direbus atau digoreng. Jenis makanan yang dikonsumsi dari golongan makanan yang mengandung karbohidrat sebagai sumber energi, sehingga mencukupi energi untuk beraktifitas .

Tabel 4 menunjukkan konsumsi informan dari golongan padi-padian masih didominasi dari golongan beras. Semua informan mengkonsumsi beras setiap hari. Gandum yang merupakan bahan impor merupakan komoditas ke dua terbanyak yang dikonsumsi informan. Informan mengkonsumsi olahan gandum dengan frekuensi yang berbeda. Terbanyak $37 \%$ informan mengkonsumsi 4-6 kali seminggu, $50 \%$ informan mengkonsumsi 1-3 kali seminggu, dan $13 \%$ informan mengkonsumsi 1-3 kali sebulan. Jagung yang merupakan bahan pangan lokal hanya dikonsumsi oleh $80 \%$ informan, dengan frekuensi $31 \%$ informan mengkonsumsi 1-3 kali seminggu, dan $44 \%$ informan mengkonsumsi 1-3 kali sebulan. Tinggi persentase konsumsi beras disebabkan karena di lokasi penelitian adalah wilayah pertanian dengan agroekosistem sawah dan dominan ditanami padi. Tingginya tingkat partisipasi konsumsi beras terkait dengan pola pangan tunggal yaitu beras sebagai makanan pokok utama. Walaupun tidak semua rumah tangga mengusahakan tanaman padi, tetapi umumnya berasal dari membeli, dan menjadikan beras sebagai makanan pokok utama.

Diversifikasi konsumsi pangan pokok tidak dimaksudkan untuk mengganti beras secara total tetapi mengubah pola konsumsi pangan masyarakat sehingga masyarakat akan 
mengkonsumsi lebih banyak jenis pangan dan lebih baik gizinya. Pangan yang dikonsumsi akan beragam, bergizi dan berimbang. Image atau citra bahwa pangan hanya disimbolkan dengan beras semata adalah merupakan inti permasalahannya. Semua orang seperti didorong makan nasi alias beras. Padahal masih banyak sumber pangan lain yang dapat kita manfaatkan untuk mengganti ataupun melengkapi konsumsi beras ini. Ada singkong, ubi jalar, sagu, jagung, kentang, dan masih banyak bahan alternatif lainnya yang nilai gizinya tidak kalah, bahkan memiliki kelebihan dibandingkan beras.

Semua responden mengakui jika makanan pokok mereka adalah beras, sedangkan golongan jagung dan gandum hanya digunakan sebagai makanan selingan. Hal ini sesuai yang dituliskan oleh Ariani dan Ashari (2003) yang menunjukkan jumlah konsumsi beras (persentase jumlah orang yang mengkonsumsi beras) di berbagai wilayah cukup tinggi hampir mencapai 100 persen, yang berarti hampir semua rumah tangga telah mengkonsumsi beras. Kecenderungan tersebut tidak hanya terjadi pada rumah tangga perkotaan tetapi juga rumah tangga di pedesaan, walaupun umumnya tingkat partisipasi di desa masih lebih rendah daripada di kota. Bila dilihat antar pulau, maka tingkat partisipasi konsumsi beras tidak jauh berbeda antara pulau yang satu dengan pulau yang lain, yaitu hampir 100 persen.

Beras selain sumber energi dan protein utama dalam pola konsumsi masyarakat, juga sebagai wage goods dan political goods. Banyak kepentingan publik dihasilkan oleh beras, dan beras berperanan dalam ketahanan pangan, stabilitas ekonomi dan lapangan kerja. Kebijakan pemerintah seperti penetapan harga dasar gabah dan pengendalian harga di tingkat konsumen mendorong masyarakat untuk mengkonsumsi beras. Walaupun tingkat konsumi beras cenderung menurun, namun volume konsumsi beras masih jauh lebih tinggi dibandingkan dengan umbi-umbian dan jagung.

Tabel 4. Perubahan Konsumsi Pangan Pokok (Kg/Kapita/Tahun)

\begin{tabular}{ccccccc}
\hline Tahun & Beras & Jagung & Terigu & Ubikayu & Ubijalar & Sagu \\
\hline 2002 & 115,5 & 3,4 & 8,5 & 12,8 & 2,8 & 0,3 \\
2005 & 105,2 & 3,3 & 8,4 & 15,0 & 4,0 & 0,5 \\
2008 & 104,9 & 2,9 & 11,2 & 12,9 & 2,8 & 0,5 \\
\hline
\end{tabular}

Sumber :SUSENAS, Badan Ketahanan Pangan 2016.

Sebagai gambaran konsumsi beras pada tahun 2008 mencapai $104,9 \mathrm{~kg}$, yang berarti 36,2 kali lebih besar dibandingkan konsumsi jagung (2005 : 31,9 kali), daripada konsumsi jagung; 9,4 kali konsumsi terigu dan 8,1 kali konsumsi ubikayu dan 37,5 kali konsumsi ubijalar.

\section{Simpulan}

Partisipasi Kelompok Wanita dalam pemamfaatan sumber pangan keluarga melalui pemanfaatan lahan pekarangan di Kecamatan Mattiro Sompe Kabupaten Pinrang secara optimal dilaksanakan oleh
$50 \%$ responden atau 40 orang kelompok wanita P2KP. Pola konsumsi pangan pokok masih mengandalkan beras sebagai bahan makanan pokok. Umbi-umbian hanya diolah sebagai bahan cemilan atau kue yang dijadikan sebagai makanan selingan. Akibatnya tingkat Diversifikasi pangan pokok masih belum sesuai dengan pola pangan ideal yang tertuang dalam PPH. Konsumsi dari padi - padian lebih besar dari yang dianjurkan dalam program P2KP, sebaliknya untuk umbi-umbian masih lebih kecil dari yang seharusnya. 


\section{Daftar Pustaka}

Ariani, M dan Ashari. 2003. Arah, Kendala dan Pentingnya Diversifikasi Konsumsi Pangan di Indonesia. Forum Agro Ekonomi.Vol. 21, No. 2.Desember. Bogor.

BKP- Badan Ketahanan Pangan 2013. Pedoman Umum Gerakan Percepatan Penganekaragaman Konsumsi Pangan (P2KP), Badan Ketahanan Pangan Deptan, Jakarta. 2016. Pedoman Pelaksanaan Program Percepatan Penganekaragaman Konsumsi pangan (P2KP) Tahun 2016. Direktori Pengembangan Konsumsi Pangan Kementerian Pertanian, Jakarta.

Dwiratna, N.P. S., Widyasanti, A., dan Rahmah, D.M. 2016. Pemanfaatan Lahan Pekarangan Dengan Menerapkan Konsep Kawasan Rumah Pangan Lestari. Dharmakarya: Jurnal Aplikasi Ipteks untuk Masyarakat Vol. 5, No. 1, Mei 2016: 19 - 22

Halimah, Andi Sitti. 2016. Makna Konversi Lahan Bagi Petani dan Pemangku Kepentingan Lainnya (Studi Kasus Di Kecamatan Tellulimpoe dan Kecamatan Awangpone Kabupaten Bone). Desertasi. Program Studi Ilmu Pertanian Unhas, Makassar.

Hanafie, R. 2010. Peran Pangan Pokok Lokal Tradisional dalam Diversifikasi Konsumsi Pangan. JSEP Vol. 4 No. 2 Juli 2010 (pp 17).

Hastuty, Sri. 2013. Kontribusi Program P2KP Terhadap Pendapatan Kelompok Wanita Tani Di Kelurahan Takkalala Kecamatan Wara Selatan Kota Palopo. Jurnal Dinamika, Vol. 04. No. 2 September 2013 (19-31).

IstiKhomah, dan Rhina Uchyani Fajarningsih. 2016. Potensi dan
Prospek Pemanfaatan Lahan Pekarangan Terhadap Pendapatan Rumah Tangga. Proceeding Seminar Nasional Peningkatan Kapabilitas UMKM dalam Mewujudkan UMKM Naik Kelas.pp 155-161

Krisnamurthi B. 2003. Penganekaragaman Pangan: Pengalaman 40 Tahun dan Tantangan Ke Depan. Jurnal Ekonomi Rakyat 2(7).

Kusmiati, A. dan Sholikhah, U. 2015. Peningkatan Pendapatan Keluarga melalui Pemanfaatan Pekarangan Rumah dengan Menggunakan Teknik Vertikultur. Jurnal Inovasi dan Kewirausahaan Volume 4 Nomor 2, Mei 2015, Hal. 94-101

Mahyuni. 2012. Analisis situasi dan kebutuhan konsumsi pangan di Provinsi Riau. Bogor: Institut Pertanian Bogor; 2012.

Martianto, D., Dodik Briawan, Mewa Ariani, Nita Yulianis. 2009. Percepatan Diversifikasi Konsumsi Pangan Berbasis Pangan Lokal : Perspektif Pejabat Daerah dan Strategi Pencapaiannya. Jurnal Gizi dan Pangan, Nopember 2009 4(3): $123-131$

Nurwati, N., Surtinah, Amalia. 2015. Analisis Pemanfaatan Pekarangan Untuk Mendukung Ketahanan Pangan Di Kecamatan Rumbai Pesisir Kota Pekanbaru. Jurnal Ilmiah Pertanian Vol. 11 No. 2, Februari 2015 (pp 1-8)

Rachman HPS dan Ariani M. 2008. Penganekaragaman konsumsi pangan di Indonesia: permasalahan dan implikasi untuk kebijakan dan program. Jurnal Analisis Kebijakan Pertanian Volume 6(2), (140-154).

Rahayu M, dan Prawiroatmojo. 2005. Keanekaragaman Tanaman Pekarangan dan Pemanfaatannya di Desa Lampeapi Pulau Wawoni Sulawesi Tenggara. Jurnal 
Teknologi Lingkungan P3TLBPPT

$6(2): 362-364$

Safitri, AM., Dina Rahayuning Pangestuti, Ronny Aruben. 2017. Hubungan Ketahanan Pangan Keluarga dan Pola Konsumsi Dengan Status Gizi Balita Keluarga Petani. Jurnal Kesehatan Masyarakat (e-Journal) Volume 5, Nomor 3, Juli 2017 (120-128).

Saputri, R. ,Lily Arsanti Lestari, Joko Susilo. 2016. Pola Konsumsi Pangan dan Tingkat Ketahanan Pangan Rumah Tangga di Kabupaten Kampar Provinsi Riau. Jurnal Gizi Klinik Indonesia Vol 12 No 3 - Januari 2016 (123-130).

Siti Nurul Rofiqo Irwan, Rohlan Rogomulyo, Sri Trisnowati. 2018. Pemanfaatan Pekarangan Melalui Pengembangan Lanskap Produktif di Desa Mangunan, Kabupaten Bantul Yogyakarta. Jurnal Ilmu Pertanian Indonesia (JIPI), Vol. 23 (2): 148-157 Agustus 2018

Suyastiri, Ni Made. 2008. Diversifikasi Konsumsi Pangan Pokok Berbasis Potensi Lokal dalam Mewujudkan Ketahanan Pangan Rumah Tangga Pedesaan Di Kecamatan Semin Kabupaten Gunung Kidul. Jurnal Ekonomi Pembangunan Vol 13 No 1 April 2008 (pp 51-60). 
Halaman ini sengaja dikosongkan 